\title{
MENANAMKAN NILAI-NILAI BUDAYA UNTUK MEMPERERAT INTEGRASI BANGSA
}

\author{
Lamri \\ Institut Agama Hindu Negeri Tampung Penyang Palangkaraya \\ bawiayahfda@gmail.com
}

\begin{abstract}
Riwayat Jurnal
Artikel diterima :-

Artikel direvisi : :-

Artikel disetujui : -
\end{abstract}

\begin{abstract}
Abstrak
Luas wilayah bangsa Indonesia yang terdiri dari kurang lebih 17.508 pulau yang sebagian besar sudah berpebduduk yang memiliki keragaman suku, budaya, adat istiadat dan agama yang saling berinteraksi dalam memenuhi kebutuhannya sehari-hari baik kebutuhan secara fisik maupun spiritualnya. Fenomena ini terjadi di seluruh wilayah bangsa Indonesia, sehingga dengan keadaan yang demikian sering kita jumpai berbagai permasalahan yang timbul dalam masyarakat seperti permasalahan sara, sebab yang sering dimunculkan dalam kehidupan masyarakat adalah kata "perbedaan" bukan keragaman, sehingga perbedaan itulah yang tertanam pada pola pikir sebagian bangsa Indonesia sehingga dapat menimbulkan konflik. Perbedaan yang terjadi dalam kehidupan masyarakat tedak seutuhnya seperti yang dimaksudkan "Bhineka Tunggal Ika", dan jika keragaman yang selalu kita junjung tinggi dalam kehidupan masyarakat maka kita tentu akan mengerti arti hidup yang saling membutuhkan di lingkungan social masyarakat. Oleh sebab itu Keragaman tersebut harus disadari oleh seluruh bangsa Indonesia dalam rangka menjaga dan mempertahankan persatuan dan integrasi bangsa dengan memahami nilai-nilai budaya baik budaya daerah maupun budaya nasional untuk memupuk rasa persatuan dan kesatuan bangsa untuk mencapai cita-cita sebagaimana yang telah diamanatkan oleh UndangUndang Dasar 1945 yaitu mencapai masyarakat adil dan makmur yang dijiwai oleh nilainilai Pancasila.
\end{abstract}

Kata kunci : Menanamkan, Nilai-Nilai Budaya, Integrasi Bangsa

\section{PENDAHULUAN}

Bangsa Indonesia adalah bangsa yang kaya terhadap keberagaman suku, agama, ras, budaya, tradisi, serta adat istiadat pada setiap wilayah atau daerah. Bangsa Indonesia meliliki kurang lebih
17.508 pulau besar dan kecil yang sudah diberikan nama maupun yang belum diberikan nama serta memiliki lebih dari 300 suku bangsa, dan pada setiap wilayah atau daerah terdapat berbagai budaya yang beraneka ragam bahkan terdapat 
beberapa suku yang mendiaminya. Dimana setiap suku bangsa memiliki kebudayaan yang berbeda-beda antara satu dengan yang lain. Dalam setiap suku bangsa pada suatu daerah atau wilayah terdapat kebudayaan yang berbeda-beda serta masing-masing suku bangsa tersebut memiliki norma sosial masing-masing yang mengikat masyarakat di dalamnya, sehingga kehidupan masyarakatnya akan terjadi keharmonisan, ketentraman maupun keselarasan dalam menjalankan segala aktifitas sehari-hari.

Setiap suku bangsa di setiap wilayah atau daerah di Indonesia memiliki norma-norma sosial yang berbeda-beda sebagai pengatur dan pedoman hidup masing-masing, dalam hal cara pandang terhadap suatu masalah atau tingkah laku juga memiliki perbedaan. Ketika terjadi pertentangan antar individu atau masyarakat yang berlatar belakang suku bangsa yang berbeda, mereka akan mengelompok menurut asal-usul daerah dan suku bangsanya (primodialisme). Sebagai akibat perilaku masyarakat demikian itu menyebabkan pertentangan serta ketidakseimbangan dalam suatu masyarakat (disintegrasi), dampak perilaku masyarakat yang kompleksitas pada masyarakat majemuk tidak hanya ditandai oleh perbedaan-perbedaan horisontal, seperti yang dapat kita jumpai pada perbedaan suku, ras, bahasa, adatistiadat, dan agama. Namun, juga terdapat perbedaan vertikal, berupa capaian yang diperoleh melalui prestasi (achievement). Indikasi perbedaan-perbedaan tersebut tampak dalam strata sosial ekonomi, posisi politik, tingkat pendidikan, kualitas pekerjaan dan sebagainya.

Pada kehidupan setiap masyarakat sering kita jumpai konflik-konflik sosial, pertentangan sosial bahkan sampai pada kerusuhan sosial yang melibatkan antarsuku. Sementara pada suku tertentu bukan dilahirkan untuk memusuhi suku lainnya, bahkan tidak pernah ditemukan pada salah satu suku atau daerah yang memberi doktrin atau ajaran mana pun di Indonesia yang secara absolut menanamkan permusuhan etnik.

Untuk menuju integrasi bangsa yaitu perlu adanya keserasian, keselarasan keseimbangan antar suku bangsa diperlukan toleransi antar masyarakat yang hidup dalam suatu daerah atau wilayah sehingga menuju Indonesia bersatu maju dan mandiri. Selain itu kita sebagai bangsa Indonesia menyadari bahwa faktor sejarah merupakan hal yang tidak bisa ditinggalkan sebagai suatu hal yang memiliki peran penting untuk mempersatukan suku bangsa ini. Selain itu sebagai warganegara Indonesia perlu menyadari merasa mempunyai nasib dan kenyataan yang sama di masa lalu. Sebagai bangsa Indonesia mempunyai semboyan Bhineka Tunggal Ika, yaitu walaupun kita hidup dalam keragaman, tetapi memiliki tujuan hidup yang sama, serta kita akui bahwa Pancasila sebagai ideologi yang menjadi cita-cita dan tujuan bersama untuk menuju integrasi, kedaulatan dan kemakmuran bersama.

\section{PEMBAHASAN}




\subsection{KERAGAMAN BUDAYA}

Keragaman adalah suatu kondisi dalam masyarakat dimana terdapat perbedaaan2 dalam berbagai bidang terutamasuku bangsa, ras, agama, ideologi, budaya (masyarakat yang majemuk). keragaman dalam masyarakat adalah sebuah keadaaan yang emnunjukkan perbedaan yang cukup banyak macam atau jenisnya dalam masyarakat. Keragaman berasal dari kata ragam . berdasarkan Kamus Besar Bahasa Indonesia (KBBI), contoh ragam seperti:

1. Sikap, tingkah laku, cara

2. Macam, jenis

3. Musik, lagu

4. Warna, corak

5. Laras (tata bahasa) Ada tiga macam istilah yang digunakan untk menggambarkan masyarakat yang majemuk yang terdiri dari ras, agama, bahasa dan budaya yang berbeda yaitu masyarakat pural, masyaraakat heterogen, dan masyarakat multikultural. (Herimanto 2009:97)

\subsection{BENTUK KERAGAMAN BUDAYA BANGSA INDONESIA}

Kebudayaan berasal dari bahasa Sansekerta, yaitu "buddhayah" yang merupakan bentuk jamak dari 'buddhi" (budi atau akal). Kebudayaan diartikan sebagai hal -hal yang berkaitan dengan budi dan akal. Sedang dalam bahasa Inggris, kebudayaan dikenal dengan istilah culture yang berasal dari bahasa Latin "colere", yaitu mengolah, mengerjakan tanah, membalik tanah atau diartikan bertani. Sehingga Secara umum
Koentjaraningrat membagi Kebudayaan terdiri dari beberapa Unsur yaitu :

1. Bahasa.

2. Sistem Pengetahuan.

3. Sistem Kemasyarakatan atau Organisasi Sosial.

4. Sistem Peralatan Hidup dan Teknologi.

5. Sistem Mata Pencaharian Hidup.

6. Sistem Religi.

7. Kesenian.

\subsection{KARAKTERISTIK BUDAYA}

Budaya memiliki sifat universal, artinya terdapat sifat-sifat umum yang melekat pada setiap budaya, kapan pun dan dimanapun budaya itu berada. Adapun sifat itu adalah :

1. Kebudayaan adalah milik bersama.

2. Kebudayaan merupakan hasil belajar.

3. Kebudayaan didasarkan pada lambang.

4. Kebudayaan terintegrasi.

5. Kebudayaan dapat disesuaikan.

6. Kebudayaan selalu berubah.

7. Kebudayaan bersifat nisbi (relatif).

Dalam kebudayaan juga terdapat pola-pola perilaku (pattern of behavior) yang merupakan cara-cara masyarakat bertindak atau berkelakuan yang harus diikuti oleh semua anggota masyarakat tersebut. Adapun subtansi atau isi utama budaya adalah:

1. Sistem pengetahuan, berisi pengetahuan tentang alam sekitar, flora dan fauna sekitar tempat tinggal, zat-zat bahan mentah dan 
benda-benda

dalam

lingkungannya, tubuh manusia, sifat-sifat dan tingkah laku sesama manusia serta ruang dan waktu. .

2. Sistem nilai budaya, adalah sesuatu yang dianggap bernilai dalam hidup.

3. Kepercayaan, inti kepercayaan itu adalah usaha untuk tetap memelihara hubungan dengan mereka yang sudah meninggal.

4. Persepsi, yaitu cara pandang dari individu atau kelompok masyarakat tentang suatu permasalahan.

5. Pandangan hidup, yaitu nilai-nilai yang dipilih secara selektif oleh masyarakat. Pandangan hidup dapat berasal dari norma agama (dogma), ideologi negara atau renungan atau falsafah hidup individu.

6. Etos budaya, yaitu watak khas dari suatu budaya yang tampak dari luar

\subsection{BUDAYA DAERAH}

Budaya daerah merupakan adat istiadat, kebudayaan yang sudah berkembang (maju) atau sesuatu yang menjadi kebiasaan yang sukar diubah yang terdapat disuatu daerah tertentu. Budaya daerah umumnya bersifat tradisional yang masih dipertahankan. Menurut Fischer, kebudayaan kebudayaan yang ada di suatu wilayah berkembang disebabkan oleh beberapa faktor antara lain lingkungan geografis, induk bangsa dan kontak antarbangsa. Dari pendapat tersebut dapatlah kita kaitkan dengan kebudayaan daerah yang ada di Indonesia yang memiliki ciri-ciri khusus antarwilayah sehingga beraneka ragam.

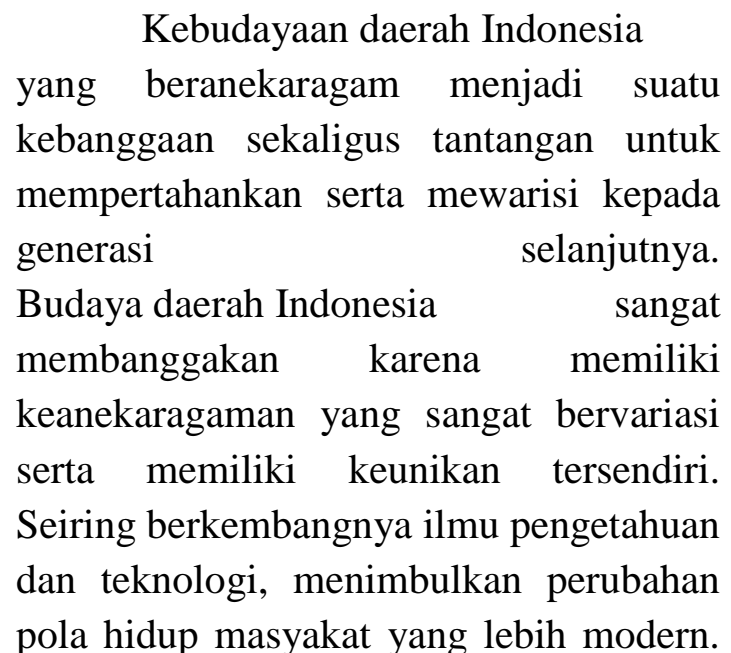
Akibatnya, masyarakat lebih memilih kebudayaan baru yang mungkin dinilai lebih praktis dibandingkan dengan budaya lokal.

Dalam lingkungan budaya nasional yang bervariasi demikian, setiap masyarakat Indonesia sebaiknya tidak ada yang merasa mendapat perlakuan diskriminatif. Budaya demikian diharapkan dapat memberikan rasa kesatuan dan persatuan bagi setiap warga negara Indonesia, yang merupakan perekat yang sangat diperlukan, salah satu unsur budaya yang dapat berperan ialah bahasa Indonesia yang menjadi bahasa persatuan untuk bangsa Indonesia melalui Sumpah Pemuda 28 Oktober 1928.

Walaupun Indonesia menurut Van Volenholen terdiri dari 19 wilayah hukum adat, tetapi pada dasarnya Indonesia terdiri dari ratusan suku bangsa yang bermukim di wilayah yang tersebar dalam ratusan pulau yang ada di Inonesia. Tiap 
suku bangsa ini memiliki ciri fisik, bahasa, kesenian, adat istiadat yang berbeda. Dengan demikian dapat dikatakan bangsa Indonesia sebagai negara yang kaya akan budaya. Beberapa aspek keberagaman budaya Indonesia antara lain suku, bahasa, agama dan kepercayaan, serta kesenian. Kekayaan budaya ini merupakan daya tarik tersendiri dan potensi yang besar untuk pariwisata serta bahan kajian bagi banyak ilmuwan untuk memperluas pengetahuan dan wawasan. Hal yang utama dari kekayaan budaya yang kita miliki adalah adanya kesadaran yang dimiliki oleh setiap warga Negara dan bangga akan kebudayaan yang kita miliki serta bagaimana dapat memperkuat budaya nasional sehingga terciptanya kesadaran untuk mencapai kesatuan bangsa atau "nation" bahwa kebudayaan yang berkembang adalah budaya yang berkembang dalam sebuah NKRI sehingga memperkuat integrasi bangsa, disamping itu keberagaman budaya bangsa Indonesia juga merupakan sumber penghasilan (in come) bagi bangsa Indonesia.

Selain beberapahal tersebut diatas terhadap keberagaman budaya bangsa Indonesia juga terdapat permasalahan berkaitan dengan keberagaman budaya itu sendiri yaitu adanya konflik yang berlatar belakang perbedaan suku dan agama. Banyak pakar menilai akar masalah konflik ialah kemajemukan masyarakat, atau adanya dominasi budaya masyarakat yang memilki potensi tinggi dalam kehidupan serta adanya ikatan primordialisme baik secara vertikal maupun horisontal. Disamping itu kesenjangan kelompok masyarakat dalam bidang ekonomi, kesempatan memperoleh pendidikan atau mata pencaharian juga dapat mengakibatkan kecemburuan, petentangan sosial yang dapat menimbulkan konflik sehingga mengarah kepada disintegrasi bangsa

\subsection{HUBUNGAN BUDAYA DAERAH DAN BUDAYA NASIONAL.}

\section{Budaya Daerah (lokal) yang} bernilai positif, bersifat luhur dapat mendukung budaya nasional. Dalam pembangunan kebudayaan bangsa, nilainilai budaya positif baik budaya daerah perlu dipertahankan dilestarikan dan dikembangkan karena justru menjadi akar atau sumber budaya nasional. Mengingat budaya bangsa merupakan "hasil budidaya rakyat Indonesia seluruhnya" maka cepat lambat pertumbuhannya tergantung kearifan peran serta seluruh masyarakatnya. Bagaimana peran keluarga, sekolah dan pemerintah menanamkan budaya daerah pada generasi berikutnya dan kearifan generasi muda dalam melestarikan budaya daerah. Masyarakat merupakan kelompok manusia hidup dalam suatu aturan tentunya yang memiliki budaya masingmasing, sehingga masyarakat adalah orang-orang yang hidup bersama yang menghasilkan kebudayaan, sehingga tidak ada masyarakat yang tidak menghasilkan kebudayaan dengan demikian bahwa tidak ada kebudayaan tanpa masyarakat sebagai wadah dan pendukungnya, untuk 
itu budaya nasional bersumber dari budaya daerah

Ki Hajar Dewantara menyatakan kebudayaan nasional adalah "puncakpuncak dari kebudayaan daerah”, Kutipan pernyataan ini merujuk pada paham "Kesatuan" makin dimantapkan, sehingga "ketunggalikaan" makin lebih dirasakan daripada "kebhinekaan". Definisi yang diberikan oleh Koentjaraningrat dapat dilihat dari peryataannya: "yang khas dan bermutu dari suku bangsa mana pun asalnya, asal bisa mengidentifikasikan diri dan menimbulkan rasa bangga, itulah kebudayaan nasional". Pernyataan ini merujuk pada puncak-puncak kebudayaan daerah dan kebudayaan suku bangsa yang bisa menimbulkan rasa bangga bagi orang Indonesia jika ditampilkan untuk mewakili identitas bersama.

Jadi dari pendapat tersebut dapat disimpulkan bahwa kebudayaan nasional bangsa Indonesia merupakan kumpulan berbagai kebudayaan daerah yang diadopsi atau yang dapat mewakili masing-masing kebudayaaan daerah menjadi kebudayaan nasional, sehingga dari kebinekaan dalam bidang budaya/kebudayaan akan sangat dirasakan oleh seluruh bangsa Indonesia sebagai akibat dari diangkatnya kebudayaan daerah menjadi kebudayaan nasional tersebut yang secara keseluruhan dapat mengankat harkat dan martabat bangsa Indonesia baik ke dalam maupun keluar mengingat bangsa Indonesia merupakan bagian dari bangsa-bangsa yang ada di dunia yang tidak terlepas dari berbagai interaksi maupun hubungan.
Kebudayaan bangsa Indonesia terkenal dengan istilah "Budaya Timur" yaitu dicirikan dengan adat-istiadat, tradisi, bahasa, religi dan sebagainya dengan berpedoman kepada etika dan moral, hal ini telah dirumuskan dalam Pancasila ssebagai wujud jati diri bangsa Indonesia. Untuk meningkatkan kesadaran seluruh bangsa Indonesia maka pemerintah melalui perubahan ke 4 (empat) Undang-Undang Dasar Negara Republik Indonesia tahun 1945 yang terdapat pada pasal 32 ayat 1 menyatakan : Negara memajukan kebudayaan nasional Indonesia di tengah peradaban dunia dengan menjamin kebebasan masyarakat dalam memelihara dan mengembangkan nilai-nilai budayanya, dan pasal 32 ayat 2 menyatakan : Negara menghormati dan memelihara bahasa daerah sebagai kekayaan budaya nasional.(MPR RI 2013:106).

Seperti yang terdapat pada penjelasan pasal 32 Undang-Undang Dasar 1945 bahwa Kebudayaan bangsa adalah kebudayaan yang timbul sebagai buah usaha budinya rakyat Indonesia seluruhnya, serta pada alinia ke dua menyatakan bahwa Kebudayaan lama dan asli yang terdapat sebagai puncak-puncak kebudayaan daerah-daerah di seluruh Indonesia, terhitung sebagai kebudayaan bangsa. Usaha kebudayaan harus menuju kearah kemajuan adab, budaya, persatuan, dengan tidak menolak bahan-bahan baru dari kebudayaan asing yang dapat memperkembang atau memperkaya kebudayaan bangsa sendiri, serta 
mempertinggi derajat kemanusiaan bangsa Indonesia (MPR RI 2013:43).

Sesuai dengan pasal 32 UndangUndang Dasar 1945 serta penjelasanya diatas negara memberikan jaminan kepada seluruh warga negara atau suku bangsa untuk mempertahankan budaya daerah masing-masing dengan memperhatikan etika, moral, harkat, martabat demi tercapainya cita-cita bangsa yaitu mencapai masyarakat yang cerdas, tentram, damai, adil dan makmur baik dalam bidang material maupun spiritual.

\subsection{INTEGRASI BANGSA}

Integrasi bangsa Indonesia mendapat sejarah yang sangat panjang yaitu sejak gerakan Boedi Oetomo tahun 1908 yang dilanjutkan dengan Sumpah Pemuda pada tanggal 28 Oktober 1928. Indonesia merupakan negara multikultural, dimana beragam suku, agama, ras, budaya dan golongan hidup bersama dalam satu atap yaitu NKRI. Keberagaman tersebut merupakan suatu kekayaanyang luar biasa yang dianugrahkan tuhan, namun keberagaman tersebut bisa menjadi potensi komflik yang besar, manakala prinsip Bhinneka Tunggal Ika tidak diterapkan oleh kita semua. Ketika komflik terjadi, maka ancaman disintegrasi nasional akan mudah terjadi. Walaupun bangsa Indonesia menyatakan kemerdekaannya, tetapi negara Indonesia masih banyak mengalami penjajahan dari dalam dan luar negeri. Dengan adanya kesadaran seluruh warga bangsa Indonesia telah menjadi kekuatan yang sangat besar dan sudah terbukti dengan segala hal yang mengganggu ketentraman bangsa indonesia. Berbicara masalah integritas, maka dibawah ini kami akan membahas tentang pengertian integrasi, macammacam integrasi serta faktor-faktor terbentuknya integrasi.

Istilah integrasi berasal dari bahasa inggris yaitu integration yang berarti pembauran hingga menjadi kesatuan yang utuh dan bulat. integrasi juga berarti proses mengkoordinasikan berbagai tugas, fungsi dan bagian-bagian, sedemikian rupa dapat bekerja sama dan tidak saling bertentangan dalam pencapaian sasaran dan tujuan. Menurut Paul B.Horton, integrasi yaitu proses pengembangan masyarakat yang mana segenap kelompok ras dan etnik mampu berperan secara bersama-sama dalam kehidupan budaya dan ekonomi. Oleh karena integrasi suatu yang diharapkan dalam kehidupan masyarakat, maka harus tetap dijaga kelangsungannya. Integrasi nasional identik dengan integrasi bangsa yang berarti suatu prosespenyatuan atau perubahan berbagai aspek sosial budaya kedalam suatu wilayah dan pembentukan nasional atau bangsa.

Integrasi nasional dapat diartikan penyatuan bagian-bagian yang berbeda dari satu masyarakat menjadi suatu keseluruhan yang utuh, atau memadukan masyarakat-masyarakat kecil yang banyak jumlahnya menjadi suatu bangsa. Integrasi yang dimaksud disini adalah kesatuan dan persatuan negara. Secara umum, integrasi nasional mencerminkan proses persatuan orang-orang dari 
berbagai wilayah yang berbeda, atau memiliki berbagai perbedaan baik suku, budaya, dan dari berbagai latar belakang.

\subsection{PERAN LEMBAGA PENDIDIKAN TERHADAP PENANAMAN NILAI BUDAYA UNTUK MEMPERKUAT INTEGRASI BANGSA.}

Lembaga pendidikan mendapat posisi yang strategis untuk menanamkan nilai-nilai budaya yang bercirikan budaya bangsa Indonesia sebagai wujud implementasi nilai-nilai Pancasila sebagai jiwa bangsa Indonesia. Penenaman nilai budaya yang menjadi ciri dan pedoman hidup dan pengatur hidup masyarakat setempat perlu didukung oleh lembaga pendidikan baik lembaga pendidikan informal, formal, maupun non formal.

Dengan demikian pendidikan menjadi kunci utama dalam membentuk karakter bangsa keluarga merupakan pendidikan dasar untuk membentuk pribadi anak yang memiliki peranan yang sangat penting terhadap pendidikan anak, antara lain:

a) Pengalaman Pertama Masa Kanak-kanak

Lembaga pendidikan keluarga memberikan pengalaman pertama yang merupakan faktor penting dalam perkembangan pribadi anak, sebab dari sinilah keseimbangan jiwa didalam perkembangan individu selanjutnya ditentukan.

b) Menjamin Kehidupan Emosional Anak

Kehidupan emosional merupakan salah satu faktor yang terpenting dalam membentuk pribadi seseorang, karena adanya kelainan-kelainan dalam perkembangan pendidikan individu oleh kurang berkembangnya kehidupan emosional secara wajar.

c) Menanamkan Dasar Pendidikan Moral

Dalam sebuah keluarga perilaku orang tua menjadi teladan oleh seorang anak dan anak suka meniru perbuatan orang tuanya. "Rasa cinta, rasa bersatu dan lainlain perasaan dan keadaan jiwa yang pada umumnya sangat berfaedah untuk berlangsungnya pendidikan, teristimewa pendidikan budi pekerti, terdapatlah di dalam hidup keluargadalam sifat yang kuat dan murni.

d) Memberikan Dasar Pendidikan Sosial

Yaitu dengan menumbuhkan benih-benih kesadaran sosial lewat tolong-menolong dalam kehidupan keluarga, gotong royong, menjaga ketertiban, kedamaian danlain-lain.

e) Peletakan Dasar-dasar Keagamaan Mengenalkan ilmu-ilmu agama, mengajari mengaji al-quran dan lain-lain. Hal ini sangat memupuk keagamaan anak.

Pendidikan sekolah pada dasarnya merupakan lanjutan dari pendidikan kelu arga hanya saja pendidikan di sekolah dip eroleh secara teratur, sistematis, bertingka $\mathrm{t}$, dan dengan mengikuti syarat yang jelas dan ketat. Dapat dikatakan pendidikan se kolah merupakan pembentukan kecerdasa $\mathrm{n}$, minat serta bakat pada anak untuk dike mbangkan. Peranan sekolah yaitu: 
a. Anak didik belajar bergaul sesama anak didik, antara guru dengan an ak didik dan antara anak didik den gan orang yang bukan guru.

b.Anak didik belajar menaati peratur an-peraturan sekolah.

c.Mempersiapkan anak didik untuk menjadi anggota masyarakat yang berguna

Masyarakat merupakan lembaga ketiga setelah keluarga dan sekolah. Pendidikan dalam masyarakat dampaknya lebih luas. Corak dan ragam pendidikan yang dialami seseorang dalam masyarakat banyak sekali, meliputi segala bidang, baik pembentukan kebiasaankebiasaan, pembentukan pengertianpengertian (pengetahuan) sikap dan minat, maupun pembentukan kesusialaan dan keagamaan. Jadi dapat dikatakan bahwa pendidikan masyarakat merupakan aplikasi dari pendidikan keluarga dan sekolah. Dalam pendidikan masyarakat ini lebih kepada pendidikan penyesuaian terhadap masyarakat. Ketiga lembaga pendidikan tersebut melakukan kerjasama diantara mereka baik secara langsung maupun tidak langsung, dengan saling menopang kegiatan yang sama secara sendirisendiri maupun bersamasama. Dengan kata lain, perbuatan mendidik yang dilakukan oleh orang tua terhadap anak juga dilakukan oleh sekolah dengan memperkuatnya serta dikontrol oleh masyarakat sebagai lingkungan bagi lingkungan sosial anak. Lembaga pendidikan adalah suatu lembaga yang bertujuan mengembangkan potensi manusiawi yang dimiliki anakanak agar mampu menjalankan tugastugas kehidupan sebagai manuasia, baik secara individual maupun sebagai anggota masyarakat. Kegiatan untuk mengembangkan potensi itu harus dilakukan secara berencana, terarah dan sistematik guna mencapai tujuan tertentu.

\subsection{FAKTOR-FAKTOR YANG MEMPENGARUHI INTEGRASI BANGSA}

Sebagai bangsa yang memiliki wilayah yang sangat luas yang terdiri dari kurang lebih 17.508 pulau besar dan kecil yang didiami oleh masyarakat atau penduduk yang memiliki ciri, tradisi, budaya yang berbeda-beda, maka terdapat berbagai faktor mempengaruhi integrasi nasional sebagai berikut:

a. Faktor dari luar

b. Factor dari dalam

c. Faktor wilayah

a. Masyarakat Indonesia yang heterogen (beraneka ragam) dalam faktor-faktor kesukubangsaan dengan masing-masing kebudayaan daerahnya, bahasa daerah, agama yang dianut, ras dan sebagainya.

b. Wilayah negara yang begitu luas, terdiri atas ribuan kepulauan yang dikelilingi oleh lautan luas.

c. Besarnya kemungkinan ancaman, tantangan, hambatan dan gangguan yang merongrong keutuhan, kesatuan dan persatuan bangsa, baik yang berasal dari dalam maupun luar negeri. 
d. Masih besarnya ketimpangan dan ketidakmerataan pembangunan dan hasil-hasil pembangunan menimbulkan berbagai rasa tidak puas dan keputusasaan di masalah SARA (Suku, Agama, Ras, dan Antar-golongan), gerakan separatisme dan kedaerahan, demonstrasi dan unjuk rasa.

e. Adanya paham "etnosentrisme" di antara beberapa suku bangsa yang menonjolkan kelebihan-kelebihan budayanya dan menganggap rendah budaya suku bangsa lain.

\subsection{PENTINGNYA PERSATUAN DALAM KERAGAMAN}

Fenomena yang ada dalam kehidupan sehari-hari dimana di satu daerah atau daerah tempat tinggal sering dijumpai sejumlah suku bangsa yang tidak hanya satu suku bangsa. Sehingga perlu disadari bahwa bangsa Indonesia yang berdasarkan Pancasila sesuai sila ke 3 (tga) yaitu Persatuan Indonesia serta pasal 1 (satu) UUD 1945 menyatakan “ Negara Indonesia ialah negara kesatuan yang berbentuk Republik". Hal ini merupakan dasar dan pedoman hidup berdampingan dalam masyarakat mengingat bahwa Pancasila merupakan inti dari semua nilai moral yang diambil dari jiwa bangsa Indonesia.

Dengan demikian hubungan terjadi sudah sejak zaman dahulu baik yang dilakukan oleh orang/ individu, kelompuk maupun organisasi. Banyak suku bangsa dari satu pulau pindah ke pulau yang lain. Mereka menetap di tempat yang baru. Jadilah penduduk setempat. Kemudian menjadi penduduk desa atau kelurahan, kecamatan dan kabupaten atau kota. Ada juga program transmigrasi yang menyebabkan bercampurnya suatu suku bangsa asli dengan suku pendatang.

Masing-masing dari mereka memiliki budaya yang berbeda. Tidak hanya budaya, agama mereka pun juga mungkin berbeda. Suatu tempat yang terdapat suku dan budaya yang beragam tentunya sangat rawan dan dapat menyulut adanya perpecahan antarsuku. Namun ternyata hal ini tidak terjadi karena bangsa Indonesia memegang teguh semboyan Bhineka Tunggal Ika. Bhinneka Tunggal Ika berarti berbedabeda tetapi tetap satu juga. Kata Bhineka Tunggal Ika diambil dari kitab Sutasoma karangan Empu Tantular, seorang pujangga dari Majapahit. Bunyi selengkapnya adalah Bhineka Tunggal Ika Tan Hana Dharma Mangrwa. Semboyan bangsa Indonesia ini tertulis pada kaki lambang negara Garuda Pancasila. Bhinneka Tunggal Ika merupakan alat pemersatu bangsa. Untuk itu kita harus benar-benar memahami maknanya. Negara kita juga memiliki alat-alat pemersatu bangsa yang lain, yakni:

1. Dasar Negara Pancasila

2. Bendera Merah Putih sebagai bendera kebangsaan

3. Bahasa Indonesia sebagai bahasa nasional dan bahasa persatuan

4. Lambang Negara Burung Garuda

5. Lagu Kebangsaan Indonesia Raya

6. Lagu-lagu perjuangan 
Masih banyak alat-alat pemersatu bangsa yang sengaja diciptakan agar persatuan dan kesatuan bangsa tetap terjaga. Bisakah kamu menyebutkan yang lainnya? Persatuan dalam keragaman memiliki arti yang sangat penting. Persatuan dalam keragaman harus dipahami oleh setiap warga masyarakat agar dapat mewujudkan hal-hal sebagai berikut :

1. Kehidupan yang serasi, selaras dan seimbang

2. Pergaulan antarsesama yang lebih akrab

3. Perbedaan yang ada tidak menjadi sumber masalah

4. Pembangunan berjalan lancer

Adapun sikap yang perlu dikembangkan untuk mewujudkan persatuan dalam keragaman antara lain:

1. Tidak memandang rendah suku atau budaya yang lain

2. Tidak menganggap suku dan budayanya paling tinggi dan paling baik

3. Menerima keragaman suku bangsa dan budaya sebagai kekayaan bangsa yang tak ternilai harganya

4. Lebih mengutamakan negara daripada kepentingan daerah atau suku masing-masing Kita mesti bangga, memiliki suku dan budaya yang beragam. Keragaman suku dan budaya merupakan kekayaan bangsa yang tak ternilai harganya. Bangsa asing saja banyak yang berebut belajar budaya daerah kita. Bahkan kita pun sempat kecolongan, budaya asli daerah kita diklaim atau diakui sebagai budaya asli bangsa lain. Karyakarya putra daerah pun juga banyak yang diklaim oleh bangsa lain.

\subsection{HUBUNGAN KERAGAMAN BUDAYA INTEGRASI INDONESIA \\ TERHADAP BANGSA}

Sifat majemuk dari bangsa Indonesia, disamping merupakan kebanggaan hendaknya pula dilihat bahwa suatu negara dengan keanekaragaman suku-bangsa dan kebudayaan mengandung potensi konflik. Oleh karenanya guna menuju suatu integrasi nasional Indonesia yang kokoh, terdapat berbagai kendala yang harus diperhatikan. Dalam rangka mempersatukan penduduk Indonesia yang beraneka warna, Koentjaraningrat (1982:345-346) melihat ada empat masalah pokok yang dihadapi, ialah

1. Mempersatukan aneka-warna suku-bangsa,

2. Hubungan antar umat beragama,

3. Hubungan mayoritas-minoritas dan

4. integrasi kebudayaan di Irian Jaya dengan kebudayaan Indonesia.

Diantara sekitar 220 juta orang penduduk Indonesia dewasa ini, sulit diketahui secara pasti distribusi jumlah dari masing-masing suku-bangsa. Terakhir kalinya, Sensus Penduduk di Indonesia yang memuat items sukubangsa adalah yang dilakukan oleh pemerintah kolonial Hindia Belanda; 
yang hasilnya dimuat dalam Volkstelling (1930). Sensus Penduduk Indonesia yang dilakukan pada 1970 dan dalam dasawarsa berikutnya, tidak mencantumkan items suku-bangsa. Mengingat hal tersebut, ada kesulitan untuk mengetahui secara pasti laju pertumbuhan penduduk berdasarkan suku-bangsa dan distribusi mereka.

Koentjaraningrat (1982:346-347) menilai bahwa berapakah sebenarnya jumlah suku-bangsa di Indonesia, sampai saat kini masih sukar ditentukan secara pasti. Hal ini disebabkan ruang lingkup istilah konsep suku-bangsa dapat mengembang atau menyempit, tergantung subyektivitas. Sebagai contoh, paling sedikit di Pulau Flores terdapat empat suku-bangsa yang berbeda bahasa dan adat-istiadatnya, ialah orang Manggarai, Ngada, Ende-Lio dan Sikka. Namun kalau mereka ada di luar Flores, mereka biasanya dipandang oleh suku-bangsa lainnya atau mereka mengidentifikasikan dirinya sebagai satu suku-bangsa, ialah Flores.

Setidaknya terdapat kurang lebih 252 suku-bangsa yang masing-masing memakai bahasa yang berbeda. Mengingat hal tersebut maka, Koentjaraningrat memandang perlu upaya pendifinisian konsep suku-bangsa di Indonesia secara ilmiah, antara lain dengan mengambil beberapa unsur kebudayaan sebagai indikator yang dapat berlaku bagi semua "suku-suku-bangsa" yang ada di Indonesia. Upaya untuk memahami keanekaragaman suku-bangsa dan kebudayaan di Indonesia adalah sekaligus berpotensi pula mengungkapkan berbagai bentuk interaksi sosial yang terjadi di kalangan suku-bangsa yang saling berbeda kebudayaannya. Dengan mempelajari proses interaksi sosial yang terjadi, sekaligus diharapkan akan memberikan pengetahuan tentang proses-proses sosial di kalangan mereka sehingga akan diketahui segi dinamis dari masyarakat dan kebudayaan. Berbagai perubahan dan perkembangan masyarakat yang merupakan segi dinamis adalah akibat interaksi sosial yang terjadi diantara para warganya, baik orang perorangan, orang dengan kelompok maupun antar kelompok manusia. proses-proses sosial yang perlu diperhatikan dalam rangka studi hubungan antar suku-bangsa, terutama untuk mempercepat terwujudnya integrasi nasional Indonesia yang kokoh.

Faktor integrasi bangsa Indonesia rasa senasib dan sepenanggungan serta rasa seperjuanagan di masa lalu ketika mengalami penjajahan. Penjajahan menimbulkan tekanan baik mental ataupun fisik. Tekanan yang berlarut-larut akan melahirkan reaksi dari yang ditekan ( di jajah ). Sehingga muncul kesadaran ingin memperjuangkan kemerdekaan. Dengan kesadaran ini, maka keberagaman suku atau golongan yang ada di Indonesia tidak dipermasalahkan semuanya bersatu, berjuang untuk merdeka. Sehingga terbentuklah negara Kesatuan Republik Indonesia dengan semboyannya Bhineka Tunggal Ika. Selain itu, sumpah pemuda merupakan salah satu faktor integrasi bangsa karena isinya adalah persatuan 
yaitu berbangsa satu, bertanah air satu dan berbahasa satu Indonesia.

Faktor disintegrasi bangsa di antaranya ialah negara yang berbentuk kepulauan yang dipisahkan oleh lautan, sehingga akan memunculkan sikap ingin menguasai daerah sendiri dan tidak mau diatur.Kemudian keberagaman suku, ras, agama bisa memicu disintegrasi bangsa, karena setiap golongan pasti mempunyai budaya, watak, dan adat yang berbeda dan yang pasti mereka masing-masing mempunyai ego kesukuan ( Chauvinisme ) sehingga kan mudah konflik dengan suku-suku yang lain. Faktor disintegrasi yang lain ialah rasa ketidakadilan yang memicu pemberontakan kepada yang berbuat tidak adil. Jika pemerintah Indonesia tidak berbuat adil pada setiap daerah yang ada di Indonesia maka akan menimbulkan rasa ketidakpuasan dari masyarakat yang berdomisili di daerah tersebut, sehingga pada akhirnya ada keinginan untuk memisahkan diri dari Negara Kesatuan Republik Indonesia.

Kemajemukan bangsa Indonesia yang meliputi bahasa, budaya,suku, agama dan ras, bisa menjadi daya integrasi maupun disintegrasi bangsa kita. Seperti yang kita ketahui, dengan bahasa persatuan yaitu bahasa Indonesia kita dapat berkomunikasi antar suku dan ras sehingga hubungan akan terjalin dengan baik dan dapat mempererat persaudaraan sebagai satu bangsa besar yaitu bangsa Indonesia. Selain itu, keragaman antar budaya termasuk bahasa akan saling melengkapi satu sama lainnya menjadi kebudayaan nasional yang akan menjadi kebanggaan semua suku dan ras yang ada di Indonesia. Dan yang ke dua, kemajemukan bangsa kita juga dapat menjadi daya disintegrasi bangsa karena dengan keragaman itu, rentan sekali terhadap konflik antar suku dan daerah, terutama masalah agama seperti yang terjadi akhir-akhir ini di kawasan timur Indonesia. Selain faktor kemajemukan budaya, penyebab disintegrasi bangsa Indonesia juga terpicu oleh sentralisasi pembangunan yang selama ini lebih terfokus di pulau Jawa, sehingga menyebabkan kesenjangan dan kecemburuan dari daerah lain, sehingga timbul keinginan untuk memisahkan diri dari NKRI.

Yang bisa menjadi salah satu faktor pendorong integrasi bangsa yang menjadi semboyan bangsa Indonesia yang terkenal dengan Bhineka Tunggal Ika, dimana kita terpisah-pisah oleh laut, sungai tetapi kita mempunyai ideologi yang sama yaitu pancasila. Sedangkan yang menjadi faktor desintegrasi bangsa adalah kurang adanya rasa nasionalisme, toleransi, serta kesadaran warganegara sebagai bangsa Indonesia serta campur tangan pihak asing dalam masalah bangsa Indonesia sendiri.

\section{PENUTUP}

\subsection{Simpulan}

Di tengah arus reformasi dewasa ini, agar selamat mencapai Indonesia Baru, maka ideologi yang harus lebih diingat-ingat dan dijadikan landasan kebijakan mestinya harus berbasis pada konsep Bhinneka Tunggal Ika. Artinya, sekali pun berada dalam satu kesatuan, 
tidak boleh dilupakan, bahwa sesungguhnya bangsa ini berbeda-beda dalam suatu kemajemukan. Maka, Indonesia Baru yang kita citakan itu, hendaknya ditegakkan dengan menggeser masyarakat majemuk menjadi masyarakat multikultural, dengan mengedepankan keBhinnekaan sebagai strategi integrasi nasional. Namun, jangan sampai kita salah langkah, yang bisa berakibat yang sebaliknya: sebuah konflik yang berkepanjangan. Harus disadari, bahwa merubah masyarakat majemuk ke multukultural itu merupakan perjuangan panjang yang berkelanjutan.

\subsection{Saran}

Untuk menjaga keharmonisan integrasi bangsa Indonesia,perlu lebih di tingkatkan toleransi antar masyarakat yang mempunyai tingkat keanekaragaman yang sangat tinggi. Selain itu perlu adanya control nasional untuk menjaga keseimbangan nasional.

\section{DAFTAR PUSTAKA}

Koentjaraningrat, 2004, Manusia dan Kebudayaan di Indonesia, Jakarta : Jambatan.

Koentjaraningrat, 2009. Pengantar Ilmu Antropologi, Jakarta: Rineka Cipta.

Koentjaraningrat, 1970, Keseragaman dan Aneka Warna Masyarakat Irian Barat, Jakarta, Lembaga Research Kebudayaan Nasional.

Robert F. Murphy, 1986, Cultural and Social Anthropologi, London: Prentice-hal International. 